\title{
Innovativeness of Enterprises in Poland in a Regional Context
}

\section{Anna Golejewska}

\begin{abstract}
The article examines the innovativeness of enterprises in 69 Polish NUTS3 sub-regions in 2014. The analysis is based on unpublished regional data from the Polish Central Statistical Office covering the following variables: the share of enterprises which have incurred outlays for innovative activities, the share of enterprises implementing process or product innovations, the share of companies collaborating in the field of innovation, and the share of new or modernized products in total production sold in industrial companies. The analysis focuses on building rankings and cluster analysis of NUTS3 regions. As research methods, the author uses selected methods of multidimensional comparative analysis, principal component analysis and the hierarchical Ward's method. The results show that there are substantial differences among NUTS3 sub-regions as regards innovativeness of enterprises. The low level of cooperation does not foster innovation. Innovation outputs of enterprises are also unsatisfactory. The highest variation is seen in the share of new or modernized products in total production sold in industrial companies. The final effect of the cluster analysis is the division of regions into 7 groups. In the case of units where innovation inputs are not reflected in innovation outputs, it would be useful to explore regional and local factors influencing those relations. Further research is still needed.

Keywords: innovation, enterprises, regional differences.
\end{abstract}

\section{INTRODUCTION}

In the majority of the EU countries, there is a noticeable outflow of enterprises from innovative activity. The same applies in Poland, particularly to service enterprises. In well-developed economies with accumulated innovation potential this trend does not entail such enormous risks as in less innovative countries. Despite the declining percentage of innovative firms in Poland, one can observe an increase in expenditure on innovation, but it still remains below

1 Anna Golejewska, Ph.D., Economics of European Integration Department, University of Gdańsk, ul. Armii Krajowej 119/121, 81-824 Sopot, Poland, e-mail: a.golejewska@ug.edu.pl. 
the EU average. The level of cooperation between Polish enterprises seems to be quite favorable in comparison to other countries; nevertheless, innovation cooperation remains unsatisfactory (Zadura-Lichota, 2015, pp. 5-63).

The activity of companies determines innovativeness at a national, regional and local level. Researchers on innovation issues often underline the importance of regions in the innovation process. There exists extensive evidence that knowledge and innovation are concentrated in selected regions, sub-regions or cities (Simmie, 2003; Nowakowska, 2009; Siłka, 2012; Golejewska, 2013; Golejewska, 2012). A region, through its specific assets including knowledge, learning ability, organizational culture, infrastructure, etc., has an impact on the competitiveness of local businesses and their innovative activity. Local competitive advantages result from a concentration of highly specialized knowledge, the presence of public institutions, competition, trade partners and consumers (Pinto, 2009).

The aim of the paper is to examine disproportions in innovativeness between enterprises in 69 Polish NUTS3 sub-regions in 2014. To achieve the main objective of the paper, the following detailed objectives are expected to be met: 1) presentation of the literature review; 2 ) empirical research on the innovativeness of Polish firms covering the creation of rankings and cluster analysis, and finally 3) conclusions.

\section{LITERATURE REVIEW}

Innovation has been and continues to be an important topic of study for a number of different disciplines, including economics, business, engineering, science, and sociology. The importance and role of knowledge assets in determining competitiveness, productivity, and finally output growth is a frequent theme in the spatial and non-spatial literature (Harris, 2008, p. 16).

Technology consists of three key elements: knowledge, skills and artefacts. Technological innovation involves "the process of applying knowledge and skills to combine an existing set of artifacts into a novel combination that fill a market demand and thereby create value" (Wolfe, 2011, p. 44). A firm is a central actor for the effectuation of innovation and technological change. Innovativeness determines the standards and directions of development of an enterprise, and thus its development and competitive advantage. Through a process of competition, firms with new products make firms with old products redundant and firms with more efficient modes of production eliminate less-efficient producers from the market. Differences in total factory productivity account for roughly half the differences in income across countries and are generally associated with differences in technological progress (Hall \& Jones, 1999). Firms 
introducing new products and new methods of production and distribution directly enhance economic growth (Bosma, Schutjens \& Stam, 2011, p. 483).

A region may be regarded as an "innovation incubator" which provides appropriate conditions for the setting up and the development of innovative companies, as well as pro-innovation behavior among other important entities in a territory. Recent literature calls into question whether innovations emerge from the single inventor or even in whole internally within a firm or organization (Amara, Landry \& Lamari, 2003; Wolfe, 2009; Johnson, 2011). Knowledge-based transformations should not be understood as the results of the actions of firms alone, "but as a structural characteristic of knowledgebased economies" (Leydesdorff, 2001, p. 4) and "a social process that depends on interaction and learning" (Hall, 2010, p. 10). The literature indicates various "territorial innovation systems" (Lagendijk, 1997; Moulaert \& Mehmood, 2010). Their typology often includes industrial districts (focused on the growth dynamics of small and medium-sized enterprises), innovative milieu, regional innovation systems, clusters and learning regions (Lagendijk, 1997; Porter, 2000; De Propris \& Crevoisier, 2011). The last ones may be treated as a general synthesis of the above-mentioned concepts (Moulaert \& Mehmood, 2010).

Innovation is a complex and multidimensional activity that cannot be measured directly or with a single indicator. Measuring innovation has been studied extensively by scholars and practitioners. In the literature, even "innovation economics" exists - a sub-discipline that analyses the relationship between investments in innovation and their financial outcomes. Innovation indicators are split into four groups-generations, from less to more complex. The first group, focusing on a linear model of innovation, includes such indicators as R\&D investment, research personnel, university graduates, etc. The second group is extended by output indicators. The third generation is focused on a wider set of innovation indicators and indexes based on surveys and the integration of publicly available data. The fourth generation is currently at an embryonic stage and includes knowledge, networks, risk, clusters, management techniques, etc. (Gamal, 2011, p. 10).

In the literature, two broad streams of research on the measurement of innovation are noticeable. The first one concentrates on innovation inputs, such as R\&D intensity, and outputs, such as patents. Nevertheless, these measures merely concern a small part of all the possible innovation activities. Due to empirical evidence, the linkage between such measures and organizational innovativeness and economic growth is vague. An appropriate example is a research conducted by Booz (2005) based on 1000 top global innovation spenders which confirmed there was no significant relationship between R\&D spending and nearly all measures of business success. The value of patents as indicators of innovation, at a micro level, is rather limited 
(Gittleman, 2008). The second stream is focused on the macro level. In the EU, countries' innovation capabilities are measured through objective economic measures, such as the Oslo Manual (2005), the European Community Innovation, and the European Innovation Scoreboard (EIS) (Gamal, 2011, p. 9). Regional innovation performance, measured by the Regional Innovation Scoreboard, should be based on the same indicators as EIS. Nevertheless, for many of them regional data are not available and are calculated using only 18 of the $27 \mathrm{EIS}$ indicators. Some indicators relating to entrepreneurial activity belong among others: R\&D expenditure in the business sector as a percentage of GDP; SMEs innovating in-house as a percentage of SMEs; innovative SMEs collaborating with others as a percentage of SMEs; EPO patent applications per billion of regional GDP; SMEs introducing product or process innovations as a percentage of SMEs; SMEs introducing marketing or organizational innovations as a percentage of SMEs, sales of new-tomarket and new-to-firm innovations as a percentage of total turnover etc. (Hollanders \& Es-Sadki, 2017). In the paper, the author followed the approach of the Regional Innovation Scoreboard, in which input-type and output-type measures have been used simultaneously.

There have been and continue to be substantial differences among Polish regions as regards innovativeness (Kowalik, 2014; Golejewska, 2013; Górecka \& Muszyńska, 2011; Nowakowska, 2009; Siłka, 2012). According to the findings presented in the Regional Innovation Scoreboard (2017), 7 out of 16 Polish regions have been classified as moderate innovators and none as innovation leader or strong innovator. Research results show that high innovation inputs do not often correspond with high innovation outputs (Golejewska, 2013). Polish regions are also internally diversified as regards innovativeness (Brodzicki \& Golejewska, 2017). Disproportions between the best performing regions and the rest of the country are a big challenge for regional innovation policy.

\section{RESEARCH METHODS}

The group of analyzed regions consists of 69 units (out of 72 units according to the territorial breakdown of 1 January 2015). The analysis is based on unpublished regional data of the Polish Central Statistical Office covering the following variables: the share of enterprises which have incurred outlays for innovative activities, the share of enterprises implementing process or product innovations, the share of companies collaborating in the field of innovation, and the share of new or modernized products in total production sold by industrial companies. The fifth available variable - internal expenditure on research and 
development - has been omitted from the analysis due to a significant lack of data. The data cover industrial enterprises employing more than 49 people and have been extracted from innovation statements in the industry (PNT-02). The analysis was conducted for 2014, the most recent year for which data were available up to this point. Due to a lack of data, three NUT3 regions have been omitted: Bialski (PL311), Ciechanowski (PL12B) and Nowotarski (PL 219).

The empirical analysis starts with the creation and comparison of innovativeness rankings on the basis of the method of ranks and method of standardized values. Some of the differences between the ranks have been explained by the results of the principal component analysis. Finally, a cluster analysis employing the hierarchical Ward's method was conducted. The applied method is effective in building homogenous clusters with the lowest inter-group variance (Grabiński, 2003, p. 110).

\section{RESULTS AND DISCUSSION}

Descriptive statistics of the analyzed variables are presented in Table 1 . The highest coefficient of variation (75.4) was recorded for the share of sold production of new or substantively improved (modernized) goods in the sold value of industry, the lowest (19.1) for the share of enterprises which implemented process or product innovations. The results of the analysis of mean values indicate a very low level of innovation cooperation and sold production of new goods. This might suggest that there is still a mutual distrust between companies in Poland and also that they do not derive significant benefits from cooperation and implemented innovations.

Table1. Descriptive statistics

\begin{tabular}{|c|c|c|c|c|c|c|c|c|c|}
\hline Variable & & Mean & Median & Min. & Max. & $\begin{array}{l}\text { Lower } \\
\text { quartile }\end{array}$ & $\begin{array}{l}\text { Upper } \\
\text { quartile }\end{array}$ & $\begin{array}{l}\text { Standard } \\
\text { deviation }\end{array}$ & $\begin{array}{l}\text { Coefficient } \\
\text { of variation }\end{array}$ \\
\hline$\overline{X 1}$ & 69 & 28.9 & 28.2 & 15.2 & 44.7 & 23.8 & 34.0 & 6.9 & 23.9 \\
\hline$\times 2$ & 69 & 14.1 & 13.2 & 5.1 & 29.1 & 9.9 & 17.6 & 5.5 & 38.7 \\
\hline X3 & 69 & 35.7 & 36.2 & 19.6 & 48.4 & 30.5 & 40.8 & 6.8 & 19.1 \\
\hline $\mathrm{X} 4$ & 69 & 10.1 & 8.0 & 0.7 & 44.3 & 4.2 & 12.9 & 7.6 & 75.4 \\
\hline
\end{tabular}

Note: X1: share of enterprises which have incurred outlays for innovative activities in 2014 (input), X2: share of enterprises involved in innovation cooperation in 2012-2014 (input),

X3: share of enterprises which implemented process or product innovations in 2012-2014 (output), X4: share of sold production of new or substantively improved (modernized) goods introduced in 20122014 in sold value of industry in 2014 (output).

Source: own elaboration based on CSO data. 
The highest share of enterprises which incurred outlays for innovative activities was recorded in PL213: city of Kraków -44.7\%, PL523: Nyski-43.8\%, PL514: city of Wrocław and PL127: city of Warszawa $-42.7 \%$. The lowest, less than $20 \%$ - in PL116: Sieradzki, PL417: Leszczyński, PL634: Gdański, PL637: Chojnicki, PL312: Chełmsko-Zamojski, PL616: Grudziądzki and PL12D: Ostrołęcki. Enterprises implementing innovations most frequently cooperated in PL213: city of Kraków, PL326 Tarnobrzeski, PL343 Białostocki and PL514: city of Wrocław (in all sub-regions at least 25\%). The lowest share of cooperating enterprises was recorded for PL616: Grudziądzki, PL417: Leszczyński, PL636: Słupski, PL116: Sieradzki, PL345 Suwalski and PL312: Chełmsko-Zamojski. In all cases, the share did not exceed $7.5 \%$. Most of the leaders in the share of innovative enterprises were placed highly in the ranking based on implemented process or product innovations. The highest share of sold production of new or substantively improved (modernized) goods was recorded in Trójmiejski sub-region (44.3\%), the city of Łódź (31.7\%) and Ostrołęcki sub-region (25\%). The difference between the best and the worst performing sub-region was, in this case, the highest in comparison to other variables. The lowest shares amounted to $0.7 \%$ in Siedlecki and $1.9 \%$ in Przemyski sub-region. Rankings by selected variables are presented in Table 2.

Table 2. Rankings by selected variables (method of ranks)

\begin{tabular}{llllllllll}
\hline Rank & X1 & X2 & X3 & X4 & Rank & X1 & X2 & X3 & X4 \\
\hline 1 & PL213 & PL213 & PL523 & PL633 & 36 & PL432 & PL619 & PL117 & PL432 \\
2 & PL523 & PL326 & PL343 & PL113 & 37 & PL12C & PL332 & PL224 & PL332 \\
3 & PL514 & PL343 & PL127 & PL12D & 38 & PL228 & PL637 & PL344 & PL617 \\
4 & PL127 & PL514 & PL514 & PL225 & 39 & PL424 & PL634 & PL411 & PL619 \\
5 & PL415 & PL21A & PL415 & PL638 & 40 & PL218 & PL117 & PL516 & PL116 \\
6 & PL325 & PL127 & PL213 & PL129 & 41 & PL618 & PL115 & PL619 & PL22A \\
7 & PL315 & PL424 & PL21A & PL518 & 42 & PL331 & PL623 & PL426 & PL637 \\
8 & PL21A & PL523 & PL315 & PL418 & 43 & PL414 & PL344 & PL432 & PL224 \\
9 & PL343 & PL325 & PL113 & PL22B & 44 & PL517 & PL411 & PL115 & PL623 \\
10 & PL314 & PL613 & PL229 & PL218 & 45 & PL431 & PL324 & PL617 & PL424 \\
11 & PL22B & PL12A & PL217 & PL517 & 46 & PL411 & PL12E & PL114 & PL417 \\
12 & PL324 & PL415 & PL326 & PL616 & 47 & PL224 & PL622 & PL431 & PL426 \\
13 & PL113 & PL22C & PL517 & PL613 & 48 & PL427 & PL428 & PL218 & PL636 \\
14 & PL326 & PL524 & PL314 & PL325 & 49 & PL117 & PL515 & PL622 & PL12A \\
15 & PL229 & PL314 & PL129 & PL214 & 50 & PL12E & PL217 & PL515 & PL523 \\
16 & PL22C & PL22A & PL325 & PL514 & 51 & PL217 & PL638 & PL128 & PL415 \\
17 & PL524 & PL114 & PL22A & PL127 & 52 & PL621 & PL416 & PL427 & PL217 \\
\hline
\end{tabular}




\begin{tabular}{llllllllll}
\hline Rank & X1 & X2 & X3 & X4 & Rank & X1 & X2 & X3 & X4 \\
\hline 18 & PL129 & PL22B & PL418 & PL326 & 53 & PL515 & PL617 & PL331 & PL621 \\
19 & PL225 & PL516 & PL22C & PL515 & 54 & PL623 & PL12D & PL618 & PL431 \\
20 & PL22A & PL517 & PL225 & PL516 & 55 & PL617 & PL224 & PL227 & PL634 \\
21 & PL613 & PL225 & PL428 & PL114 & 56 & PL227 & PL618 & PL621 & PL331 \\
22 & PL633 & PL633 & PL613 & PL227 & 57 & PL128 & PL426 & PL414 & PL115 \\
23 & PL518 & PL113 & PL623 & PL428 & 58 & PL345 & PL12C & PL634 & PL344 \\
24 & PL418 & PL418 & PL518 & PL343 & 59 & PL115 & PL431 & PL416 & PL312 \\
25 & PL428 & PL229 & PL323 & PL22C & 60 & PL638 & PL128 & PL12D & PL427 \\
26 & PL332 & PL432 & PL22B & PL229 & 61 & PL636 & PL621 & PL636 & PL128 \\
27 & PL516 & PL227 & PL633 & PL213 & 62 & PL416 & PL218 & PL616 & PL315 \\
28 & PL619 & PL129 & PL324 & PL414 & 63 & PL12D & PL315 & PL345 & PL12C \\
29 & PL12A & PL331 & PL524 & PL524 & 64 & PL616 & PL312 & PL638 & PL622 \\
30 & PL114 & PL228 & PL214 & PL416 & 65 & PL312 & PL345 & PL228 & PL117 \\
31 & PL344 & PL427 & PL332 & PL314 & 66 & PL637 & PL116 & PL312 & PL618 \\
32 & PL214 & PL214 & PL12E & PL323 & 67 & PL634 & PL636 & PL637 & PL345 \\
33 & PL323 & PL323 & PL12A & PL411 & 68 & PL417 & PL417 & PL417 & PL324 \\
$34 ~$ & PL426 & PL518 & PL424 & PL21A & 69 & PL116 & PL616 & PL116 & PL12E \\
35 & PL622 & PL414 & PL12C & PL228 & & & & & \\
\hline
\end{tabular}

Source: own elaboration based on CSO data (2014).

Ranking considering all variables, based on the method of ranks is presented in Table 3. The leaders among cities are Wrocław, Warszawa and Kraków. The top ten also includes Łódź and sub-regions of Podkarpackie (PL325, PL326), Małopolskie (PL 21A), Podlaskie (PL343), Opolskie (PL523) and Śląskie (PL 22B). Among the ten least innovative sub-regions, three represent the region of Pomorskie. These results differ from the results obtained by the method of standardized values (Table 4). This is particularly the case for such NUTS 3 sub-regions as Trójmiejski (PL633), Rzeszowski (PL325), Bytomski (PL228), Płocki (PL12C), Skierniewicki (PL117), Łomżyński (PL344) and the City of Poznań (PL415). In those cases, the differences amount to at least six places. In the case of Trójmiejski sub-region, a significant impact on the difference has the highest value of the share of sold production. Low values of this variable in Rzeszowski and Bytomski sub-region result in their lower position in the second ranking. In other cases, the sub-regions were classified higher in ranking based on the method of standardized values. In this case, it results mainly from a high value of the share of enterprises which implemented process or product innovations in those regions. 
Table 3. Rankings of NUTS3 sub-regions (method of ranks)

\begin{tabular}{llllll}
\hline Rank & NUT 3 region & \multicolumn{2}{l}{ Rank } & NUTS 3 region & \multicolumn{2}{l}{ Rank } & NUTS 3 region \\
\hline 1 & City of Wrocław & 24 & Legnicko-Głogowski & 47 & Koszaliński \\
2 & Capital City & 25 & Krakowski & 48 & Starogardzki \\
& Warszawa & & & & \\
3 & City of Kraków & 26 & tódzki & 49 & Częstochowski \\
4 & Białostocki & 27 & Szczeciński & 50 & Inowrocławski \\
5 & Rzeszowski & 28 & Warszawski Zachodni & 51 & Skierniewicki \\
6 & Tarnobrzeski & 29 & Krośnieński & 52 & Szczecinecko-Pyrzycki \\
7 & City of Łódź & 30 & City of Szczecin & 53 & Płocki \\
8 & Oświęcimski & 31 & Sandomiersko- & 54 & Olsztyński \\
& Nyski & 32 & Pędrzejowski & & \\
9 & Suławi & 55 & Siedlecki \\
10 & Sosnowiecki & 33 & Zielonogórski & 56 & Piotrkowski \\
11 & Bielski & 34 & Włocławski & 57 & Kaliski \\
12 & Bydgosko-Toruński & 35 & Przemyski & 58 & Gorzowski \\
13 & Warszawski & 36 & Nowosądecki & 59 & Grudziądzki \\
& Wschodni & & & & \\
14 & Lubelski & 37 & Rybnicki & 60 & Chojnicki \\
15 & Trójmiejski & 38 & Pilski & 61 & Świecki \\
16 & City of Poznań & 39 & Koniński & 62 & Gdański \\
17 & Tyski & 40 & Tarnowski & 63 & Elbląski \\
18 & Poznański & 41 & Ełcki & 64 & Radomski \\
19 & Gliwicki & 42 & Bytomski & 65 & Słupski \\
20 & Wrocławski & 43 & Łomżyński & 66 & Sieradzki \\
21 & Wałbrzyski & 44 & Jeleniogórski & 67 & Leszczyński \\
22 & Opolski & 45 & Ostrołęcki & 68 & Suwalski \\
23 & Katowicki & 46 & Kielecki & 69 & Chełmsko-Zamojski \\
\hline 50 & owno & &
\end{tabular}

Source: own elaboration based on CSO data (2014).

Table 4. Rankings of NUTS3 sub-regions (method of standardized values)

\begin{tabular}{llllll}
\hline Rank & NUT 3 region & Rank & NUTS 3 region & Rank & NUTS 3 region \\
\hline 1 & City of Kraków & 24 & Warszawski Zachodni & 47 & Starogardzki \\
2 & City of Wrocław & 25 & Legnicko-Głogowski & 48 & Częstochowski \\
3 & Capital City & 26 & City of Szczecin & 49 & Ostrołęcki \\
& Warszawa & & & & \\
4 & Białostocki & 27 & tódzki & 50 & Bytomski \\
5 & Nyski & 28 & Krakowski & 51 & Kielecki \\
6 & Trójmiejski & 29 & Szczeciński & 52 & Siedlecki \\
\hline
\end{tabular}




\begin{tabular}{llllll}
\hline Rank & NUT 3 region & Rank & NUTS 3 region & Rank & NUTS 3 region \\
\hline 7 & City of Łódź & 30 & Puławski & 53 & Olsztyński \\
8 & Oświęcimski & 31 & Krośnieński & 54 & $\begin{array}{l}\text { Szczecinecko- } \\
\text { Pyrzycki }\end{array}$ \\
& Tarnobrzeski & 32 & $\begin{array}{l}\text { Sandomiersko- } \\
\text { Jędrzejowski }\end{array}$ & 55 & Inowrocławski \\
& & & & \\
10 & City of Poznań & 33 & Przemyski & 56 & Piotrkowski \\
11 & Rzeszowski & 34 & Włocławski & 57 & Gorzowski \\
12 & Bielski & 35 & Zielonogórski & 58 & Świecki \\
13 & Bydgosko- & 36 & Łomżyński & 59 & Kaliski \\
& Toruński & & & & \\
14 & Warszawski & 37 & Ełcki & 60 & Elbląski \\
& Wschodni & & & & \\
15 & Sosnowiecki & 38 & Tarnowski & 61 & Radomski \\
16 & Tyski & 39 & Nowosądecki & 62 & Gdański \\
17 & Lubelski & 40 & Pilski & 63 & Grudziądzki \\
18 & Poznański & 41 & Rybnicki & 64 & Chojnicki \\
19 & Gliwicki & 42 & Koniński & 65 & Słupski \\
20 & Katowicki & 43 & Koszaliński & 66 & Suwalski \\
21 & Opolski & 44 & Jeleniogórski & 67 & Chełmsko-Zamojski \\
22 & Wrocławski & 45 & Skierniewicki & 68 & Leszczyński \\
23 & Wałbrzyski & 46 & Płocki & 69 & Sieradzki \\
\hline Source: ownelaborationbased & & &
\end{tabular}

Source: own elaboration based on CSO data (2014).

Some of the aforementioned differences between scores might be explained by the results of principal components analysis (Górniak, 1998; Leech, Barrett \& Morgan, 2005). In the analysis, the first component is a composition of variables $x 1, x 2$ and $x 3$ and the second represents variable $x 4$. According to the scree plot, the first component explains the total variance of the analyzed variables at $66.44 \%$, the second at $22.78 \%$. Generally, the differences between rankings result from implemented methods. In ranking, each variable has in principle the same meaning but after standardization what is very important is the dispersal of observations, which is the highest for the fourth variable and thus has a greater impact on the final results of this method. From Figure 1 it is clear that Component 1 is the most significant for PL213, PL314, PL127, PL343 and PL523 and the least significant for PL116, PL417 and PL312. Component 2 remains the most significant for PL633, PL113, PL12D, PL638 and PL225 and the least significant for PL523, PL415 and PL315 (see Figure 1). 


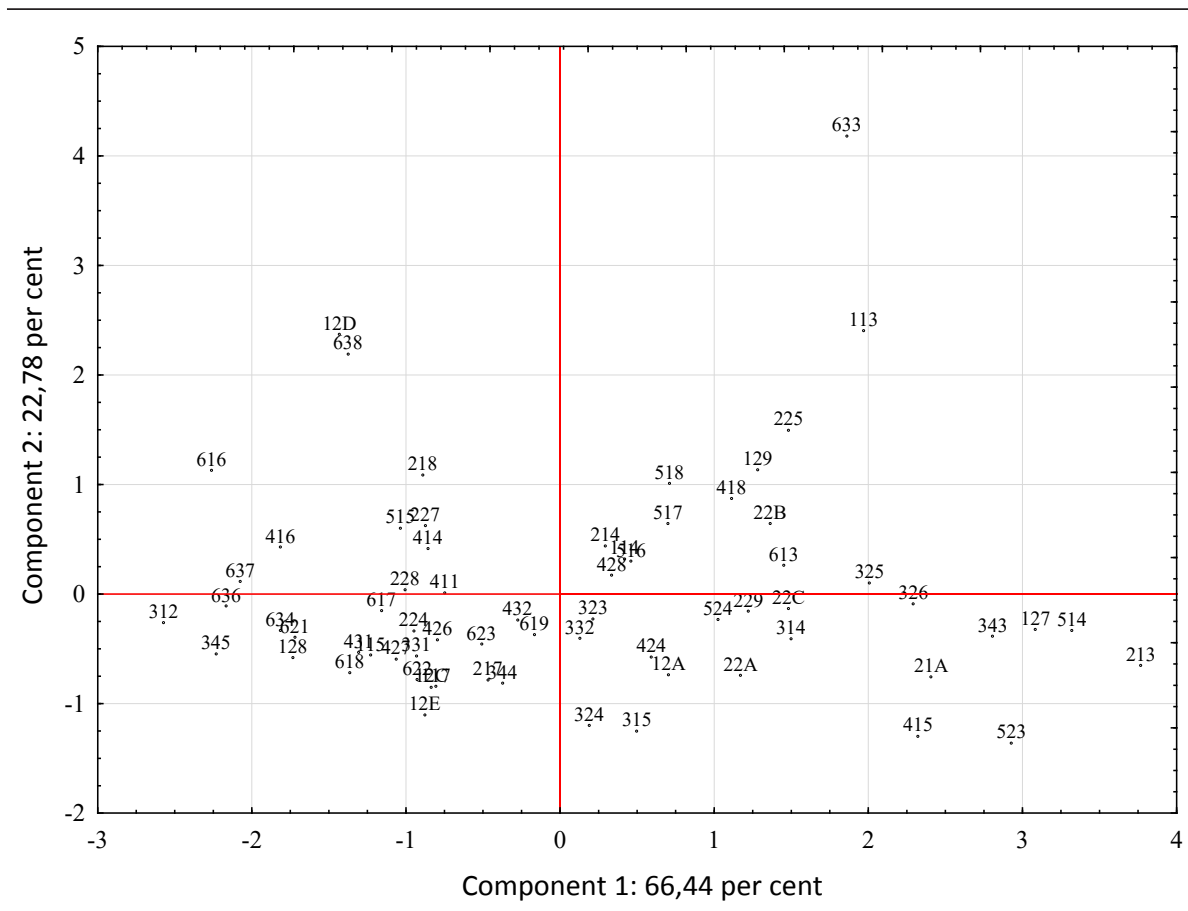

Figure 1. Results of principal component analysis

Source: own elaboration based on CSO data (2014).

The next step was the cluster analysis conducted using the hierarchical Ward's method. As a result, 69 sub-regions have been divided into 7 groups (see Table 5). The most numerous group consists of 16 NUTS3 sub-regions, the least numerous of 6 sub-regions. The results are presented graphically on the map (Figure 2).

The differences among groups were analyzed using mean values of the standardized variables (see Figure 3). The first group consists of 8 sub-regions located - apart from the capital region- in Małopolskie, Wielkopolskie, Dolnośląskie, Opolskie and in two Eastern regions: Podkarpackie and Podlaskie. It is characterized by the highest mean values of analyzed variables, apart from the value of sold production of new or substantively improved (modernized) goods which remains average. The second group comprises eight sub-regions located in Pomorskie (3 sub-regions), Wielkopolskie (2 sub-regions), Łódzkie and in two Eastern regions: Lubelskie and Podlaskie. In contrast to the previous group, the sub-regions have the lowest values of variables apart from sold production which remains low. 
Table 5. Results of cluster analysis, Ward's method

\begin{tabular}{lllllll}
\hline Group 1 & Group 2 & Group 3 & Group 4 & Group 5 & Group 6 & Group 7 \\
\hline PL514 & PL312 & PL619 & PL516 & PL515 & PL431 & PL518 \\
PL213 & PL116 & PL315 & PL517 & PL616 & PL115 & PL113 \\
PL21A & PL345 & PL432 & PL613 & PL218 & PL117 & PL129 \\
PL127 & PL634 & PL323 & PL314 & PL12D & PL217 & PL633 \\
PL523 & PL636 & PL324 & PL114 & PL638 & PL128 & PL225 \\
PL326 & PL416 & PL344 & PL214 & PL227 & PL228 & PL418 \\
PL343 & PL417 & PL332 & PL12A & PL414 & PL224 & \\
PL415 & PL637 & PL426 & PL524 & & PL331 & \\
& & PL12C & PL325 & & PL621 & \\
& & & PL229 & & PL623 & \\
& & & PL22A & & PL622 & \\
& & & PL22B & & PL411 & \\
& & & PL22C & & PL427 & \\
& & & PL424 & & PL617 & \\
& & & & PL12E & \\
\hline
\end{tabular}

Source: own elaboration based on CSO data (2014).

The third group consists of 9 NUTS3 sub-regions and is characterized by a high share of innovative enterprises in which the level of cooperation and implemented innovation remain respectively low and average while sold production is rather low.

The next group is much more numerous and consists of 15 sub-regions. It is heterogynous and it is characterized by a high share of innovative enterprises, highly involved in cooperation, a high share of enterprises which implemented innovations and an average share of sold production of new goods. The fifth group comprises 7 sub-regions with low values of all the indicators apart from high production sold. The most numerous group 6 is characterized by low values of all indicators and the lowest mean value of production sold. The last group is the least numerous one. It consists of 6 sub-regions, all located in different regions. It is characterized by the highest mean value of the share of sold production of new or substantively improved (modernized) goods.

Definite leaders of the first, best performing group are Kraków and Wrocław. In the weakest group 2, the highest innovation indicators have enterprises located in Słupski and Kaliski sub-region. In the third group, the most innovative are enterprises in Krośnieński and Puławski sub-region, and in the fourth group - enterprises located in Rzeszowski, Sosnowiecki and Bydgosko-Toruński sub-region. The leaders of the next group are enterprises of Nowosądecki and Rybnicki sub-region. The highest innovation indicators in the sixth group were recorded in Ełcki, Tarnowski and Pilski sub-region and finally, in the last group in the enterprises of Trójmiejski sub-region. 

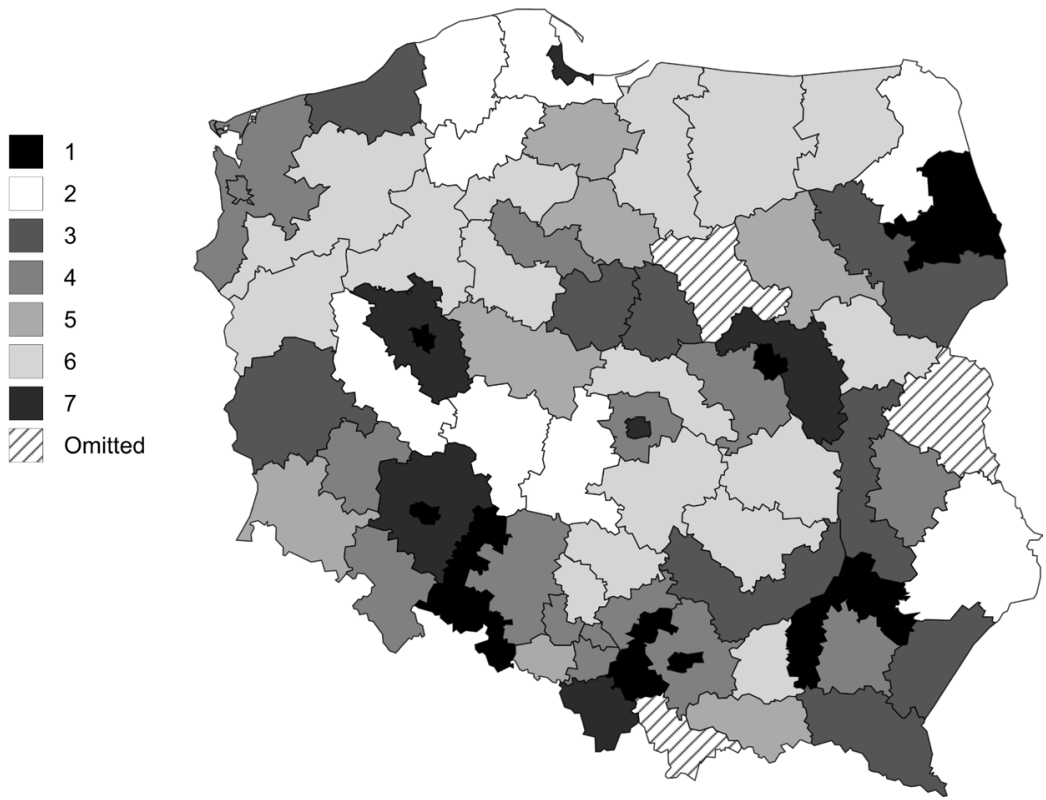

Figure 2. Results of cluster analysis, Ward's method, groups Source: own elaboration based on CSO data (2014).



Figure 3. Mean values of variables by groups of regions Source: own elaboration based on CSO data (2014). 


\section{CONCLUSION}

Results of the analysis show that there are substantial disproportions in innovativeness between industrial enterprises located in different Polish NUTS 3 sub-regions. The greatest differences are visible in the share of sold production of new goods in the sold value of industry and in the level of innovation cooperation which remains unsatisfactory. The results confirm that there might still be a mutual distrust between companies in Poland as regards innovation activity and also that they might not derive significant benefits from cooperation and implemented innovations. The ranking scores show some differences mainly due to the high dispersal of observations for the share of sold production of new products. The scores confirm dominance at the forefront of major urban centers. Among the cities, the leaders are Wrocław, Warszawa and Kraków. It is noteworthy that not many of the Eastern sub-regions performed badly. The lowest innovation indicators have enterprises in Suwalski and Chełmsko-Zamojski sub-region. It is also interesting to note that three out of the ten worst performing sub-regions are located in the region of Pomorskie. Their low position results mainly from low innovation cooperation and a low share of sold production of new goods.

The final effect of the cluster analysis is the division of regions into 7 groups, of which the first one is characterized by the highest innovativeness of industrial enterprises and the second one by the lowest. The group in which low inputs translate into low outputs is group 6 . The groups with high input variables are group 4 and group 7 . In the latter group they translate into the highest share of sold production of new products. In group 5 low inputs correspond with the second highest value of the mentioned output indicator. Finally, group 3 consists of units in which the mean values of input and output variables are mixed: low or average. The groups of sub-regions are not "homogenous geographically" which means that Polish NUTS 2 regions are internally diverse as regards innovativeness of industrial enterprises. The only exception is Warmińsko-Mazurskie. As benchmarking, it could be interesting to identify sub-regions with high innovation outputs corresponding with lower or proportionate innovation inputs. In the case of units where inputs are not reflected in outputs, it would be useful to explore regional and local factors influencing those relations. It shall be a question for further study. 


\section{References}

Amara, N., Landry, R., \& Lamari M. (2003). Social capital, innovation, territory and public policy. Canadian Journal of Regional Science, 26(1), 87-120.

Booz, A. H. (2005). Relationship between R\&D spending and sales growth, earnings, or shareholder returns. Retrieved from http://www.boozallen.com

Bosma, N., Schutjens, V., \& Stam, E. (2011). Regional entrepreneurship. In P. Cooke, B. Asheim, R. Boschma, R. Martin, D. Schwartz \& F. Toedling (Eds.), Handbook of Regional Innovation and Growth (pp. 482-494). Cheltenham: Edward Elgar Publishing.

Brodzicki, T., \& Golejewska, A. (2017). Regional variation of innovation activity in Poland. The positive role of location in metropolitan areas affirmed. Working Papers of Economics of European Integration Division, 1, 1-26.

De Propris, L., \& Crevoisier, O. (2011). From regional anchors to anchoring. In P. Cooke, B. Asheim, R. Boschma, R. Martin, D. Schwartz \& F. Toedling (Eds.), Handbook of Regional Innovation and Growth. (pp. 167-180). Cheltenham: Edward Elgar Publishing.

European Commission. (2017). Regional Innovation Scoreboard 2017. Retrieved from http://ec.europa.eu/growth/industry/innovation/factsfigures/regional_pl

Gamal, D. (2011). How to measure organization innovativeness? An overview of innovation measurement frameworks and innovation audit/ management tools. Retrieved from http://tiec.gov.eg/backend/reports/ measuringorganizationinnovativeness.pdf

Gittelman, M. (2008). Comment: The value of European Patents. European Management Review, 5, 85-89.

Golejewska, A. (2013). Input-output innovativeness of Polish regions. Social Research, 4(33), 87-97.

Golejewska, A. (2012). Innowacyjność a konkurencyjność regionalna krajów Grupy Wyszehradzkiej w latach 1999-2008. Prace Komisji Geografii Przemysłu PTG, 20, 93-115.

Górecka, D., \& Muszyńska, J. (2011). Analiza przestrzenna innowacyjności polskich regionów. Acta Universitatis Lodziensis Folia Oeconomica, 253, 55-70.

Górniak, J. (1998). Analiza czynnikowa ianaliza głównych składowych. Retrieved from https://kb.osu.edu/dspace/bitstream/handle/1811/69494/ ASK_1998_83_102.pdf

Grabiński, T. (2003). Analiza Taksonomiczna Krajów Europy w Ujęciu Regionalnym. Kraków: Wydawnictwo Akademii Ekonomicznej w Krakowie.

Hall, R. E., \& Jones, Ch. I. (1999). Why do some countries produce so much more output per worker than others?. Quarterly Journal of Economics, 114(1), 83-116.

Harris, R. (2008). Models of regional growth: Past, present and future. SERC Discussion Paper, 2.

Hollanders, H., \& Es-Sadki, M. (2017). Regional Innovation Scoreboard. Internal Market, Industry, Entrepreneurship and SMEs. European Union: Belgium. 
Kowalik, J. (2014). Regional innovativeness strategies and their impact on innovativeness of provinces in Poland. A spatio-temporal analysis. Comparative Economic Research, 17(4), 121-135.

Johnson, S. (2011). Where Good Ideas Come From. New York: Riverhead Trade. Lagendijk, A. (1997). Will the New Regionalism Survive? Tracing Dominant Concepts in Economic Geography. UK: University of Newcastle-Upon-Tyne.

Leech, N. L., Barrett, K. C., \& Morgan, G. A. (2005). SPSS for Intermediate Statistics: Use and Interpretation. Mahwah, New Jersey: Lawrence Erlbaum Associates Publishers.

Leydesdorff, L. (2001). Knowledge-based innovation systems and the model of a triple helix of university-industry-government relations. Conference on new economic windows: New paradigms for the new millennium, September 14, Sacerno, Italy.

De Mel, S., McKenzie, D., \& Woodruff, Ch. (2009). Innovative firms or innovative owners? determinants of innovation in micro, small, and medium enterprises. IZA Discussion Papers, 3962, 1-32.

Moulaert, F., \& Mehmood, A. (2010). Analysing regional development and policy: A structuralist realist approach. Regional Studies, 44(1), 103-118.

Nowakowska, A. (Ed.). (2009). Zdolności Innowacyjne Polskich Regionów. Łódź: Wydawnictwo Uniwersytetu Łódzkiego.

OECD. (2005). Oslo Manual: Guidelines for Collecting and Interpreting Innovation Data (3rd ed.). Paris: OECD.

Pinto, H. (2009). The diversity of innovation in the European Union: Mapping latent dimensions and regional profiles. European Planning Studies, 17(2), 303-326.

Porter, M. E. (2001). Clusters of Innovation: Regional Foundations of US Competitiveness. Washington DC: Council on Competitiveness.

Siłka, P. (2012). Potencjał innowacyjny wybranych miast Polski a ich rozwój gospodarczy. Prace Geograficzne, 236, 1-261.

Simmie, J. (2003). Innovation and urban regions as national and international nodes for the transfer and sharing of knowledge. Regional Studies, 37(6-7), 607-620.

Strahl, D. (1998). Taksonomia Struktur w Badaniach Regionalnych. Wrocław: Wydawnictwo Akademii Ekonomicznej.

Wolfe, D.A. (2009). 21st century cities in Canada: The geography of innovation. Retrieved from: http://www.mun.ca/harriscentre/Misc/21stCenturyCities inCanada_2009_web.pdf

Wolfe, D. (2011). Neo-Shumpeterian perspectives on innovation and growth. In P. Cooke (Ed.), Regional Innovation and Growth. Cheltenham: Edward Elgar Publishing.

Zadura-Lichota, P. (Ed.). (2015). Innowacyjna Przedsiębiorczość w Polsce. Odkryty i Ukryty Potencjał Polskiej Innowacyjności. Warszawa: PARP. 


\begin{abstract}
Abstrakt
Artykut analizuje innowacyjność przedsiębiorstw w 69 polskich podregionach NUTS3 w 2014 roku. Analiza bazuje na niepublikowanych danych regionalnych GUS obejmujqcych następujqce zmienne: udział przedsiębiorstw, które poniosły nakłady na działalność innowacyjnq; udział przedsiębiorstw, które nawiqzały współpracę w zakresie działalności innowacyjnej; udział przedsiębiorstw, które wdrożyły innowacje produktowe lub procesowe i udział produkcji sprzedanej wyrobów nowych lub ulepszonych $w$ przedsiębiorstwach przemysłowych $w$ wartości sprzedanej wyrobów ogółem. W opracowaniu przeprowadzono rankingi i analizę skupień. Zastosowane metody badawcze to wielowymiarowa analiza porównawcza, analiza głównych składowych i hierarchiczna metoda Warda. Wyniki potwierdziły istotne zróżnicowanie podregionów NUTS-3 w zakresie innowacyjności przedsiębiorstw. Niski poziom ich współpracy nie sprzyja innowacjom. Rezultaty działań innowacyjnych przedsiębiorstw również nie sq satysfakcjonujqce. Najwyższy poziom zmienności odnotowano dla udziału produkcji sprzedanej wyrobów nowych lub ulepszonych w wartości sprzedanej wyrobów ogółem. Wynikiem przeprowadzonej analizy skupień jest podział podregionów na 7 grup. W przypadku jednostek, w których potencjał nie przekłada się na innowacyjność należałoby zbadać lokalne i regionalne czynniki wpływajqce na te relacje. Niezbędne jest przeprowadzenie dalszych badań.
\end{abstract}

Słowa kluczowe: innowacje, przedsiębiorstwa, różnice regionalne.

\title{
Biographical note
}

Anna Golejewska, Ph.D., is a member of the staff of the Chair of Economics of European Integration at the Faculty of Economics of Gdańsk University. She lectures on economy and regional policy, including the system of implementation of the EU structural funds in Poland. She is a member of the Team of Experts assessing projects co-financed by the EU structural funds. She has authored publications devoted to competitiveness and innovativeness issues. She is a member of the Regional Studies Association. 